\title{
Kualitas Fisik, Mikrobiologis, dan Organoleptik Daging Ayam Broiler pada Pasar Tradisional di Bogor
}

\author{
Physical Quality, Microbiology, and Organoleptic on Broiler Meat in Bogor Traditional Market \\ Hajrawati $^{1)}$, Fadliah $\mathbf{M}^{1)}$, Wahyuni' ${ }^{1)}$ I. I. Arief ${ }^{2)}$ \\ ${ }^{1)}$ Mahasiswa Pascasarjana Ilmu Prpduksi dan Teknologi Peternakan, IPB \\ ${ }^{2}$ Depaetemen Produksi dan Teknologi Peternakan, Fakultas Peternakan,IPB
}

\begin{abstract}
In Indonesia, broiler meat is available abundant mainly in traditional market. Unfortunately, this kind of meat is perishable most physical, organoleptic, and microbiological deterioration. To conserve consumers from low quality of meat, this study was conducted to evaluate the physical, organoleptic, and microbiological quality of meat. Meat evaluated was obtained from three traditional markets determined purposively, namely A market, B market, and C market. The physical quality measured were pH and $a_{w}$; the microbiological quality were total plate count and E. coli number; the organoleptic were meat color, texture, aroma that value in hedonic and hedonic rank test. This study showed that physically the meat was not really decrease although it had $\mathrm{pH}$ higher than normal $\mathrm{pH}$ of meat. The value of $\mathrm{a}_{\mathrm{w}}$ reached was $\mathbf{0 . 8 4 - 0 . 8 5}$. The microbial contaminant was higher than the number of microbial allowed. However, organoleptic value indicated that meat were acceptable for panelists.
\end{abstract}

Keywords: Meat, Physical, Microbiological, Organoleptic

\section{PENDAHULUAN}

Daging unggas merupakan sumber protein hewani yang baik, karena mengandung asam amino esensial yang lengkap dan dalam jumlah perbandingan yang seimbang. Selain itu, daging unggas lebih diminati oleh konsumen karena mudah dicerna, dapat diterima oleh mayoritas orang (Yashoda et al. 2001) dan memiliki harga yang relatif murah (Cohen et al. 2007). Konsumsi masyarakat terhadap daging ayam khususnya ayam broiler terus meningkat dari waktu ke waktu. Berdasarkan data statistik dari tahun 20122014 rata-rata konsumsi daging ayam broiler di Indonesia perkapita perminggu sebesar $0.078 \mathrm{Kg}$ (BPS,2014). Namun peningkatan permintaan belum seiring dengan peningkatan kualitas terutama dari segi keamanan pangan dan kesehatan.

Kualitas daging ayam meliputi kualitas fisik, kimia dan biologi serta diterima atau tidaknya oleh konsumen. Secara biologi kerusakan daging ayam lebih banyak diakibatkan oleh adanya pertumbuhan mikroba yang berasal dari ternak, pencemaran dari lngkungan baik pada saat pemotongan maupun selama pemasaran. Pertumbuhan dan aktivitas mikroba dipengaruhi oleh faktor suhu penyimpanan, waktu, tersedianya oksigen dan kadar air daging.

Usaha penyediaan daging ayam khususnya daging ayam segar perlu mendapat perlakuan khusus karena daging ayam segar merupakan salah satu bahan pangan yang mudah rusak oleh mikroorganisme. Kondisi penjualan yang kurang higienis terutama pada pasar tradisional dapat menyebabkan daging ayam terkontaminasi oleh mikroorganisme baik yang bersifat patogen maupun non patogen. Mikroorganisme ini dapat merusak atau menyebabkan deteriorasi karkas atau daging sehingga secara langsung dapat mempengaruhi kualitas fisik dan kimia daging. Menurut BSN (2009), batas cemaran mikroba pada karkas dan daging ayam maksimum $1 \times 10^{6} \mathrm{cfu} / \mathrm{g}$ dan E. coli harus negatif.

Penelitian ini dilakukan untuk mengetahui kualitas fisik, mikrobiologi dan organoleptik daging ayam broiler pada beberapa pasar tradisional di kota Bogor.

\section{MATERI DAN METODA}

\section{Sampel Daging Ayam Broiler}

Penelitian ini menggunakan daging ayam broiler bagian dada yang diambil secara sampling dari 3 lokasi pasar. Pada tiap lokasi tersebut pengambilan sampel dilakukan sebanyak 3 kali sebagai ulangan. Teknik pengambilan sampel yang digunakan adalah purposive sampling dengan pertimbangan sebagai pasar tradisional. Perubah yang diamati yakni: pH, a, TPC, dan jumlah Escherichia coli. Pengujian dilakukan dilaboratorium terpadu Ilmu Produksi dan Teknologi Peternakan IPB untuk dianalisa kualitas fisik, mikrobiologis, dan organoleptiknya.

\section{Kualitas Fisik}

Pengukuran $\mathrm{PH}$ dilakukan dengan menggukana meat $\mathrm{pH}$ meter (Hanna, USA). Katoda dikalibrasi, kemudian ditusukan dalam sampel dan dibiarkan hingga angka yang tertera pada pengukuran digital tidak berubah lagi. Katoda pH meter, dibilas dengan aquades dan dikeringkan sebelum digunakan lagi (AOAC, 2005). Pengukuran nilai aktivitas air $\left(a_{w}\right)$ menggunakan $a_{w}$ meter (Novasina Ms-1). 


\section{Kualitas Mikrobiologi}

Analisis total mikroba (TPC) pada daging. Sampel ditimbang dalam cawan petri steril sebanyak $25 \mathrm{~g}$, ditambahkan $225 \mathrm{~mL}$ laruan BPW, ini merupakan pengenceran $10^{-1}$. Suspensi pengenceran $10^{-1}$ dipindahkan $1 \mathrm{~mL}$ dengan pipet steril ke dalam suspensi $9 \mathrm{ml}$ Buffered Peptone Water (BPW,Oxoid CM 0509) untuk mendapatkan pengenceran $10^{-2}$ dan seterusnya pengenceran dibuat $10^{-3}$ sampai $10^{-6}$.

Suspensi pengenceran $10^{-4}, 10^{-5}$, dan $10^{-6}$ masingmasing dipipet sebanyak $1 \mathrm{~mL}$ dan dimasukkan ke dalam cawan petri steril secara duplo lalu ditambahkam media Plate Count Agar (PCA, Oxoid CM 0325) steril sebanyak 15-20 mLyang sudah didingikan hingga temperatur 45 ${ }^{\circ} \mathrm{C} \pm 1$. Media dalam cawan yang telah berisi sampel dibiarkan hingga memadat dan diinkubasi dengan posisi terbalik selama $24-48$ jam pada suhu $37{ }^{\circ} \mathrm{C}$. Penghitungan total mikroba digunakan perhitungan koloni berdasarkan ketentuan Standard Plate Count (SPC). Penetapan jumlah koloni dilakukan dengan menggunakan metode Bacteriological Analitical Manual (BAM).

Suspensi pengenceran $10^{-1}, 10^{-2}$, dan $10^{-3}$ digunakan untuk menentukan jumlah E. coli. Sebanyak $1 \mathrm{~mL}$ dari tiaptiap pengenceran dimasukkan ke dalam cawan petri steril yang berbeda secara duplo. Kemudian cawan petri tersebut dituang media Eosin Methylene Blue Agar (EMBA, Himedia M022-500G) steril. Setelah media memadat, diinkubasi dengan posisi terbalik terbalik selama 24-48 jam pada suhu $37{ }^{\circ} \mathrm{C}$.. Setelah 24-48 jam, dilakukan penghitungan koloni E. coli.

\section{Kualitas Organoleptik}

Daging direbus sampai suhu $80^{\circ} \mathrm{C}$ diukur dengan menggunakan thermometer bimetal dan dilakukan uji pada panelis sebanyak 30 orang. Uji organoleptik berupa hedonik, terkait dengan warna, aroma, tekstur dan penampilan secara umum (Arief et al. 2014).

\section{Analisa Data}

Data fisik dan mikrobilogi dinalisis variansi dengan rancangan acak lengkap pola searah, bila terdapat perbedaan antara tiga lokasi pada selang kepercayaan $95 \%$ maka dilanjutkan dengan metode Duncan's New Multiple Range Test (DMRT) (Gaspersz, 1991). Data organoleptik diuji dengan menggunakan Kruskal-Wallis pada selang kepercayaan 95\%. Data yang tidak memenuhi kaidah statistik diuraikan secara deskriptif.

\section{HASIL DAN PEMBAHASAN}

\section{Kualitas Fisik}

Nilai $\mathrm{pH}$ dan $\mathrm{a}_{\mathrm{w}}$ merupakan merupakan indikator penting dalam menilai kualitas fisik daging. Kedua indikator tersebut terkait erat dengan keberadaan mikroba pada daging sehingga sangat menentukan tingkat keawetan dan kualitasnya. Hasil penilaian kualitas daging ayam broiler pada penelitian ini disajikan pada Tabel 1 .

Nilai $\mathrm{pH}$ daging daging ayam broiler dari ketiga pasar menunjukkan perbedaan yang tidak nyata $(\mathrm{P}>0.05)$. Kisaran $\mathrm{pH}$ daging dari ketiga pasar tersebut adalah 6.006.37. Nilai $\mathrm{pH}$ ini relatif lebih tinggi dari pada kisaran nilai
Tabel 1. Kualitas fisik daging ayam broiler pada tiga lokasi pasar tradisional yang berbeda

\begin{tabular}{llll}
\hline Parameter & Pasar A & Pasar B & Pasar C \\
\hline $\mathrm{pH}$ & $6,25 \pm 0,21$ & $6,00 \pm 0,18$ & $6,37 \pm 0,26$ \\
aw & $0,84 \pm 0,3$ & $0,85 \pm 0,3$ & $0,85 \pm 0,2$ \\
\hline
\end{tabular}

pH daging menurut pendapat Van Laack et al. (2000), yaitu 5.96-6.07 dan hasil penelitian Prayitno dan Suryanto (2012) dimana $\mathrm{pH}$ daging ayam broiler tanpa perlakuan apapun adalah 6.11-6.25. Tetapi, hasil penelitian ini masih lebih rendah dari hasil penelitian Afrianti et al. (2013), dimana daging ayam broiler tanpa perlakuan apapun memiliki $\mathrm{pH}$ rata-rata 6.79 dalam rentang masa simpan $6-12$ jam.

Berdasarkan lama waktu setelah proses pemotongan, $\mathrm{pH}$ daging ayam mengalami penurunan. Hasil penelitian Suradi (2008) menunjukkan bahwa daging ayam broiler memiliki pH 6.31 pada saat segera setelah pemotongan, kemudian mengalami penurunan dengan semakin lamanya jangka waktu setelah pemotongan, yaitu $2,4,6,8,10$, dan 12 jam dengan $\mathrm{pH}$ masing-masing 6.24 ; 6.16; 6.10; 6.02; 5.96 dan 5.82. Bila merujuk pada hasilhasil penelitian tersebut di atas maka daging ayam broiler dari ketiga pasar memiliki kisaran $\mathrm{pH}$ yang masih wajar sebagai daging konsumsi. Seyogianya daging ayam yang telah lebih dari 10 jam akan memiliki pH di bawah 6 .

Nilai $a_{w}$ hasil pengamatan pada penelitian ini adalah 0.84-0.85 (tabel 1). Ketiga nilai $\mathrm{a}_{\mathrm{w}}$ daging ayam broiler tersebut menunjukkan berbeda tidak nyata $(\mathrm{P}>0.05)$ berdasarkan pasar. Nilai $\mathrm{a}_{\mathrm{w}}$ pada penelitian ini lebih rendah dari pada hasil penelitian Milicevic et al. (2015), yakni 0.96. Meskipun lebih rendah dari hasil penelitian lain, nilai $a_{w}$ ini masih memungkinkan untuk tumbuh dan berkembangnya mikroba.

\section{Kualitas Mikrobiologi}

Jumlah bakteri total dan E. coli dari ketiga pasar tradisional disajikan pada Tabel 2. Pada tabel tersebut terlihat bahwa jumlah cemaran mikroba total telah melampaui jumlah yang diizinkan, yaitu $10^{6} \mathrm{cfu} / \mathrm{g}$. Dari ketiga pasar, hanya daging dari pasar $\mathrm{C}$ yang mengandung cemaran mikroba kurang dari $10^{6}$, yaitu $2.9 \times 10^{5}$. Sedangkan daging dari pasar B dan A mengandung jumlah bakteri yang melebihi ambang batas yang diizinkan menurut SNI 013924 tahun 2009. Namun demikian, hasil analisis statistik jumlah bakteri dari ketiga pasar tersebut tidak berbeda nyata $(\mathrm{P}>0.05)$. Total cemaran mikroba pada penelitian ini lebih tinggi dari rataan total mikroba pada daging ayam segar yang diperoleh oleh (Bintoro et al. 2006) yaitu $3,3 \times 10^{5}$ $\mathrm{cfu} / \mathrm{g}$.

Berdasarkan jumlah E. coli, daging dari semua pasar mengandung E. coli melebihi ambang batas yang diizinkan SNI, yaitu $10^{1}$. Selain itu, terdapat perbedaan

Tabel 2. Ratan Nilai TPC dan E. Coli daging ayam broiler pada tiga lokasi pasar tradisional yang berbeda

\begin{tabular}{llll}
\hline Parameter & $\begin{array}{l}\text { Pasar A } \\
\text { CFU g-1 }\end{array}$ & $\begin{array}{l}\text { Pasar B } \\
\text { CFU g- }^{-1}\end{array}$ & $\begin{array}{l}\text { Pasar C } \\
\text { CFU g }^{-1}\end{array}$ \\
\hline TPC & $8,19 \times 106$ & $9,01 \times 106$ & $2,9 \times 105$ \\
E. Coli & $5,9 \times 102 \mathrm{a}$ & $1,5 \times 103 \mathrm{a}$ & $1,1 \times 102 \mathrm{~b}$ \\
\hline
\end{tabular}


nyata jumlah cemaran E. coli dari ketiga pasar tersebut $(\mathrm{P}<0.05)$. Cemaran E. coli tertinggi adalah daging dari Pasar B. Semua sampel yang diperiksa terkontaminasi E.coli dengan jumlah yang berbeda. Adeyanju dan Ishola (2014) melaporkan daging ayam yang edarkan di Ibadan, Oyo, Nigeria terkontaminasi E.Coli 47.2 \%,di daerah India bagian timur kontaminasi E.coli sebesar $98 \%$ (Saikia dan Joshi 2010).

\section{Warna Daging}

\section{Kualitas Organoleptik}

Hasil pengamatan pada Tabel 3. Menunjukkan bahwa lokasi pengambilan sampel tidak berpengaruh nyata $(\mathrm{P}>0.05)$ terhadap warna daging ayam broiler. Data tersebut menunjukkan bahwa tingkat kesukaan panelis terhadap warna daging berada pada kisaran angka 2 (agak suka) sampai 3 (suka), sementara mutu hedonik daging berada pada kisaran angka 3 (pucat). Warna daging unggas dipengaruhi oleh beberapa faktor seperti umur, jenis kelamin, bangsa, lingkungan kandang, lingkungan pemotongan, kondisi sebelum pemotongan, kondisi pemotongan dan penyimpanan, lemak intramuskular, kandungan air daging dan pakan yang diberikan (Woelfel et al. 2002), warna daging juga dipengaruhi oleh kadar air dan $\mathrm{pH}$ daging (Qiao et al. 2001).

Tabel 3. Kualitas organoleptik daging ayam broiler pada tiga lokasi pasar tradisional yang berbeda.

\begin{tabular}{lllll}
\hline Uji & Parameter & Pasar A & Pasar B & Pasar C \\
\hline Mutu Hedonik & Warna & 3 & 3 & 3 \\
& Tekstur & 3 & 3 & 3.5 \\
& Aroma & 3.5 & 4 & 4 \\
\hline Kesukaan & Penampakan & 3 & 2.5 & 3 \\
& Warna & 3 & 2 & 3 \\
& Tekstur & 2.5 & 2.5 & 3 \\
& Aroma & 3 & 2.5 & 3 \\
\hline
\end{tabular}

\section{Tekstur Daging}

Data hasil pengamatan pada Tabel 3. Menunjukkan bahwa pengambilan sampel daging broiler pada lokasi yang berbeda tidak memberikan pengaruh yang nyata $(\mathrm{P}>0.05)$ terhadap tekstur daging. Penilaian panelis terhadap tingkat kesukaan tekstur daging berada pada kisaran angka 3 (suka), sementara mutu hedonik daging berada pada kisaran 3 (agak kasar) sampai 4 (lembut, empuk). Perbedaan tekstur daging disebabkan oleh umur, aktivitas, jenis kelamin, dan pakan (Susanti 1991).

\section{Aroma Daging}

Data hasil pengamatan pada Tabel 3. Menunjukkan bahwa pengambilan sampel daging broiler pada lokasi yang berbeda tidak memberikan pengaruh yang nyata $(\mathrm{P}>0.05)$ terhadap aroma daging. Penilaian panelis terhadap tingkat kesukaan aroma daging berada pada kisaran angka 2 (agak suka) sampai 3 (suka), sementara mutu hedonik daging berada pada kisaran 3 (agak amis) sampai 5 (khas daging, tidak amis).

\section{KESIMPULAN}

Kualitas daging ayam broiler yang dijual pada beberapa pasar tradisional di Bogor mengalami penurunan, dari semua sampel terkontaminasi bakteri E.Coli melebihi Batas Maksimum Cemaran Mikroba (BMCM) yang ditetapkan oleh Badan Standarisasi Nasional Indonesia tahun 2009. Namun semua bakteri tersebut tidak tahan terhadap suhu tinggi sehingga dengan proses pemasakan masih aman untuk dikonsumsi.

\section{SARAN}

Berdasarkan hasil penelitian ini dapat disarankan kepada pelaku penyedia daging ayam broiler untuk meningkatkan praktek higienis dan sanitasi sehingga kualitas daging broiler dapat ditingkatkan dan pencemaran mikroba daging broiler dapat diminimalisasi.

\section{DAFTAR PUSTAKA}

[AOAC] Association Official Analitycal Chemistry. 2005. Official Method of Analysis. 18th Ed. Maryland (US): AOAC International.

[BSN] Badan Standardisasi Nasional. 2008. Mutu karkas dan daging ayam.( SNI 3924:2009 ). Jakarta. Badan Standar Nasional.

Adeyanju GT, Ishola O. 2014. Salmonella and Escherichia coli contamination of poultry meat from a processing plant and retail markets in Ibadan, Oyo State, Nigeria. SpringerPlus 3(1):139.

Afrianti M, Dwiloka B, Setiani BE. 2013. Total bakteri, $\mathrm{pH}$, dan kadar air daging ayam broiler setelah direndam dengan ekstrak daun senduduk (Melastoma malabathricum L.) selama masa simpan. Jurnal Pangan dan gizi 4(7):49-56.

Bintoro VP, Dwiloka B, Sofyan A. 2006. Perbandingan Daging Ayam Segar dan Daging Ayam Bangka dengan Memakai Uji Kimia dan Mikrobiologi. Jurnal Pengembangan Peternakan Tropis 4(31):259-267.

Cohen N, Ennaji H, Bouchrif B, Hassar M, Karib H. 2007. Comparative Study of Microbiological Quality of Raw Poultry Meat at Various Seasons and for Different Slaughtering Processes in Casablanca (Morocco). The Journal of Applied Poultry Research 16(4):502-508. doi:10.3382/japr.2006-00061

Milicevic D, Trbovic D, Petrovic Z, Jakovac-Strajn B, Nastasijevic I, Koricanac V. 2015. Physicochemical and functional properties of chicken meat. Procedia Food Science 5:191-194.

Prayitno AH, Suryanto E. 2012. Kualitas Fisik dan Sensoris Daging Ayam Broiler yang Diberi Pakan dengan Penambahan Ampas Virgin Coconut Oil (VCO). Buletin Peternakan 34(1):55-63.

Qiao M, Fletcher D, Smith D, Northcutt J. 2001. The effect of broiler breast meat color on $\mathrm{pH}$, moisture, waterholding capacity, and emulsification capacity. Poult Sci 80(5):676-680.

Saikia P, Joshi S. 2010. Retail market poultry meats of North-East India-a microbiological survey for 
pathogenic contaminants. Res J Microbiol 5(1):36-43.

Suradi K. 2008. Perubahan sifat fisik daging ayam broiler post mortem selama penyimpanan temperatur ruang. Tesis. Fakultas Peternakan Universitas Padjadjaran. Bandung.

Van Laack R, Liu C-H, Smith M, Loveday H. 2000. Characteristics of pale, soft, exudative broiler breast meat. Poult Sci 79(7):1057-1061.

Woelfel R, Owens C, Hirschler E, Martinez-Dawson R, Sams A. 2002. The characterization and incidence of pale, soft, and exudative broiler meat in a commercial processing plant. Poult Sci 81(4):579-584.

Yashoda K, Sachindra N, Sakhare P, RAO DN. 2001. Microbiological quality of broiler chicken carcasses processed hygienically in a small scale poultry processing unit. Journal of food quality 24(3):249-259. 